\title{
EFEKTIVITAS INTERVENSI DEPRESI DAN JUMLAH CD4 PADA ORANG YANG HIDUP DENGAN HIV
}

\author{
Richal Grace Zefanya Uly ${ }^{1}$, Untung Sujianto ${ }^{2}$, Madya Sulisno ${ }^{2}$ \\ ${ }^{1}$ Program Studi Ilmu Keperawatan, Departemen Keperawatan, Fakultas Kedokteran, Universitas Diponegoro, J1. \\ Prof. Soedarto, Tembalang, Kec. Tembalang, Kota Semarang, Jawa Tengah, Indonesia 50275 \\ ${ }^{2}$ Divisi Keperawatan Dewasa, Departemen Ilmu Keperawatan, FakultasKedokteran, Universitas Diponegoro, \\ Diponegoro, Jl. Prof. Soedarto, Tembalang, Kec. Tembalang, Kota Semarang, Jawa Tengah, Indonesia 50275 \\ *ulyrichal@gmail.com
}

\begin{abstract}
ABSTRAK
Acquired Immunodeficiency Syndrome timbul akibat rusaknya sistem kekebalan tubuh manusia yang disebabkan oleh infeksi Human Immunodefiency Virus (HIV). Penderita penyakit HIV/AIDS semakin meningkat secara signifikan setiap tahunnya. Masalah yang dialami ODHA sangat kompleks salah satunya yaitu depresi. Depresi pada pasien HIV/AIDS disebabkan oleh banyak faktor, salah satunya yaitu karena jumlah CD4 yang menurun. Tujuan penelitian ini menggunakan pendekatan systematic review bertujuan untuk memperoleh pemahaman yang lebih tentang intervensi terhadap depresi dan jumlah CD4 pasien HIV. Metode systematic review dilakukan dengan mencari literatur-literatur yang terkait dengan tema yang diambil. Pencarian literatur diambil dari scient direct, EBSCO, proquest dan google scholar. Kata kunci yang dimasukan dalam pencarian artikel ini antara lain "intervention", "depression", "CD4 count patient HIV". Pencarian literatur dibatasi dari tahun 2014-2020, artikel diseleksi dan didapatkan 18 artikel yang sesuai dengan metode RCT, RCP, quasi experiment dan cross sectional. Hasil artikel yang didapat berasal dari beberapa negara, dari 18 penelitian mayoritas studi dilakukan di negara Indonesia dan dibeberapa negara lainnya, sedangkan intervensi terbanyak yaitu dengan melakukan berbagai macam jenis exercise (yoga, aerobik) dan mindfulness untuk penurunan depresi, sebagiannya dapat meningkatan jumlah CD4 pasien HIV. Kesimpulan tinjauan ini membantu menginformasikan beberapa intervensi yang dapat dilakukan pada ODHA, dapat menghemat biaya dan sederhana untuk dilakukan untuk menurunkan depresi dan meningkatkan jumlah CD4 pada ODHA.
\end{abstract}

Kata kunci: depresi, intervensi, jumlah CD4 pasien HIV

\section{EFFECTIVENESS OF DEPRESSION INTERVENTIONS AND CD4 COUNT FOR PEOPLE LIVING WITH HIV}

\begin{abstract}
Acquired Immunodeficiency Syndrome (AIDS) arises due to damage to the human immune system caused by infection with the Human Immunodefiency Virus (HIV). HIV / AIDS sufferers are increasing significantly every year. Problems experienced by people living with HIV are very complex one of which is depression. Depression in HIV / AIDS patients is caused by many factors, one of which is due to a decreased CD4 cell count. Purpose this study uses a systematic review approach aimed at gaining a better understanding of interventions for depression and CD4 counts of HIV patients. Method Systematic review is done by looking for literature related to the theme taken. Literature search was taken from scient direct, EBSCO, proquest and google scholar. Keywords included in the search for this article include "intervention", "depression", "CD4 count patient HIV". Literature search was limited from 2014-2020, articles were selected and 18 articles were found in accordance with the RCT, RCP, quasi experiment and cross sectional methods. Results articles obtained from several countries, from 18 studies the majority of studies conducted in Indonesia and in several other countries, while the most interventions are by doing various types of exercise (yoga, aerobics) and mindfulness to reduce depression, some of which can increase the CD4 count of HIV patients / AIDS. Conclusion this review helps inform some of the interventions that can be carried out in people living with HIV, can save costs and is simple to do to reduce depression and increase CD4 counts in people living with HIV.
\end{abstract}

Keywords: depression, intervention, CD4 cell count of HIV patients 


\section{PENDAHULUAN}

Menurut data WHO pada akhir tahun 2017, terdapat 36,9 juta orang hidup dengan HIV dengan 1,8 juta infeksi baru di tahun yang sama di dunia dan meningkat pada tahun 2018 tercatat sebanyak 37,9 juta orang, $21 \%$ penderita HIV tidak mengetahui tentang penyakit yang diderita (Kemenkes, 2017). Kementerian Kesehatan Indonesia tahun 2018 mengatakan jumlah kumulatif infeksi HIV yang dilaporkan sampai dengan Juni 2018 sebanyak 301.959 orang dari estimasi orang dengan HIV/AIDS (ODHA) jumlahnya pada tahun 2018 sebanyak 640.443 orang. Acquired Immunodeficiency Syndrome (AIDS) merupakan suatu kumpulan dari gejala atau sindrom yang timbul akibat rusaknya sistem kekebalan tubuh manusia yang disebabkan oleh infeksi Human Immunodefiency Virus (HIV) (UNAIDS, 2019).

Menurut Kemenkes 2018 penyebab kejadian HIV/AIDS untuk faktor resikonya yang paling tertinggi yaitu $73,4 \%$ heteroseksual, $16,5 \%$ homoseksual, 5\% dari ibu yang terinfeksi ke anak, $2,49 \%$ perinatal dan $0,3 \%$ melalui transfusi. Jumlah CD4 pada pasien HIV yang mengivasi sel CD4 dan membuat mereka memproduksi lebih banyak virus. Seseorang yang terinfeksi HIV mungkin merasa baik dan tidak menunjukan gejala, sedangkan setiap hari jutaan sel CD4 yang terinfeksi dihancurkan oleh virus tersebut. Secara klinis, jika jumlah CD4 kurang dari 200/ml dibutuhkan obat antiHIV yang dibutuhkan agar kekebalan tubuh tetap tejaga dan tidak sampai pada AIDS. Mekanisme molekular dari berbagai agen antiretrovirus menghambat berbagai protein fungsional dari HIV yang penting untuk mesin replikasi virus HIV terbukti mampu membuat virus HIV tersupresi, menurunkan viral load, meningkatkan CD4 T Lymphocyte count dan meningkatkan kekebalan tubuh pasien (Broder, 2009., Montaner et.al, 1999).

Berbagai macam dampak epidemi HIV/ AIDS dapat timbul pada penderita seperti dampak psikologis, ekonomi, sosial dan fisik oleh penyakit. Pada ODHA dengan tahap infeksi HIV positif, konsidi fisik yang tidak stabil dan cenderung menurun diikuti dengan berbagai gejala fisik seiring dengan perjalanan penyakit serta tekanan sosial yang begitu hebat yang didapat dari lingkungan dapat menjadi sumber depresi pada ODHA. Selanjutnya bagi ODHA yang telah memasuki tahap AIDS, kondisi kesehatan akan semakin memburuk dan menyebabkan ia tergantung dengan orang lain dan menjalani perawatan di rumah sakit menyebabkan mereka kehilangan kontak sosial yang biasa ditemui dirumah.(Kusuma, 2011). Pada sistem kekebalan tubuh seluler, sel $\mathrm{T}$ (CD4) yang masih belum terinfeksi HIV dipicu untuk menghasilkan interleukin (IL)-2 untuk mengaktivas sel NK (Natural Killer cell). Sel NK merupakan sel limfoid yang dapat menghancurkan sel yang mengandung virus. Pada sistem kekebalan humoral, IL-2 yang terbentuk mengaktivasi sel NK, Ig-A dan menghasilkan sel $\mathrm{B}$ membentuk sel plasma (anti virus) sehingga terjadi apoptosis, kerusakan sel yang terinfeksi HIV. Pada ODHA yang maladaptif tubuh akan meningkatkan kadar kortisol dalam darah sehingga menghambatrespon imun seluluer dan humoral. Apoptosis tidak terjadi menyebabkan virus megalami proliferasi dan terjadi penyebaran dengan cepat. Beberapa penelitian mengatakan gangguan fungsi imun seseorang yang disebabkan karena gangguan emosi dapat dibuktikan dengan menurunnya jumlah leukosit, gangguan respon imun dan menurunnya sel NK (Kusuma, 2011; MuñozMoreno, 2012)

Robinson mengatakan keadaan stres yang berlebian pada pasien depresi berperan penting terhadap perkembangan penyakit pada klien HIV yaitu dapat mempercepat terjadinya replikasi virus dan menekan respon klien sehingga dapat memperpendek periode HIV tanpa gejala dan mempercepat perjalanan penyakit (Robinson, Mathews, \& WitekJanusek, 2003). Benton et al mengatakan ada hubungan antara jumlah CD4 dengan peningkatan kesehatan mental dan kesejahteran. Jumlah CD4 yang lebih rendah pada ODHA bisa menjadi indikator depresi yang tidak dapat diobati. Depresi kronis dapat berdampak negatif pada proses penyakit, penurunan jumlah CD4 dan peningkatan viral load (Benton, Kee Ng, Leung, Canetti, \& Karnik, 2019; Li, Lee, Thammawijaya, Jiraphongsa, \& Rotheram-Borus, 2009)

Masalah depresi pada ODHA memerlukan penanganan yang serius karena dapat berdampak luas pada kesehatan dan kehidupannya. Sehingga penting untuk melakukan penelitian yang dapat mengatasi 
depresi dan jumlah CD4 pada ODHA. Tujuan dari penelitian dengan menggunakan pendekatan systematic review ini adalah untuk memperoleh pemahaman yang lebih tentang intervensi terhadap depresi dan jumlah CD4 pasien HIV.

\section{METODE}

Systematic review dilakukan dengan mencari literatur-literatur yang terkait dengan tema yang diambil. Pencarian literatur diambil dari scient direct, ebsco, proquest dan google scholar. Kata kunci yang dimasukan dalam pencarian artikel ini antara lain "intervention", "depression", "CD4 count patient HIV/AIDS". Pencarian pertama dengan kata kunci terdapat 6.345 artikel terkait. Lalu pencarian dibatasi rentan tahun 2014-2020 mendapat hasil 2.818 artikel, pembatasan dilakukan untuk menjaga keterkinian penulis berdasarkan hasil penelitian terbaru. Setelah membaca artikel yang didapat, peneliti membagi dalam 2 kriteria yaitu inklusi dan ekslusi. Kritera inklusi yaitu peneliti mengambil yang original artikel dan yang membahas spesifik terkait depresi dan jumlah CD4 pada pasien HIV/AIDS. Sedangkan kriteria ekslusi seperti artikel yang berupa report/laporan. Dari semua pencarian literatur didapat 6.345 artikel lalu diekslusi sebanyak 3.527 artikel dan tersisa 2.818 yang inklusi. Kemudian peneliti melakukan pencarian sesuai dengan judul dan abstrak, 2.800 artikel diekslusi. Artikel yang hanya berupa laporan sebanyak 1.802 artikel, tidak ada intervensi untuk depresi dan pemeriksaan CD4 pasien HIV/AIDS sebanyak 589 artkel, abstrak tidak tersedia sebanyak 49 artikel dan atikel yang tidak relevan atau tidak tersedia sebanyak 360 artikel dan sebanyak 18 artikel yang sesuai.

\section{HASIL}

Hasil evidance based praktice disajikan pada tabel 1 berikut ini.

Tabel 1

Evidance Based Practice (EBP)

\begin{tabular}{|c|c|c|c|}
\hline Peneliti, tahun & Negara & Tujuan & Metode \\
\hline $\begin{array}{l}\text { Heissel et al, } \\
2019\end{array}$ & Jerman & $\begin{array}{l}\text { Tujuan dari tinjauan } \\
\text { sistematis dan meta- } \\
\text { analisis ini adalah } \\
\text { untuk menguji efek } \\
\text { latihan terhadap } \\
\text { depresi dan } \\
\text { kecemasan pada } \\
\text { orang yang hidup } \\
\text { dengan HIV. }\end{array}$ & $\begin{array}{l}\text { Randomised Sepuluh studi dimasukkan } \mathrm{n}=479 \text { peserta, } 49,67 \% \\
\text { Controlled perempuan dengan HIV }>18 \text { tahun dan perbedaan } \\
\text { Trial (RCT) rata-rata terstandarisasi (SMD). Efek besar dalam } \\
\text { mendukung olahraga bila dibandingkan dengan } \\
\text { kontrol ditemukan untuk depresi (SMD }=0,84, \mathrm{CI}= \\
-1,57,-0,11, \mathrm{p}=0,02) \text { dan kecemasan }(\mathrm{SMD}= \\
\\
0.21,23, \mathrm{CI}=-2,42,-0,04, \mathrm{p}=0,04) \text {. Subkelompok } \\
\text { untuk depresi mengungkapkan efek besar pada } \\
\text { depresi untuk latihan aerobik saja }(\mathrm{SMD}=0.90,96, \\
95 \% \mathrm{CI}=-1,63,-0,30, \mathrm{p}=0,004)\end{array}$ \\
\hline $\begin{array}{c}\text { anatinasab et } \\
\text { al, } 2018\end{array}$ & Iran & $\begin{array}{l}\text { Tujuan dari penelitian } \\
\text { ini adalah untuk } \\
\text { menentukan dampak } \\
\text { dari program latihan } \\
\text { aerobik dan resistensi } \\
\text { latihan } 12 \text { minggu } \\
\text { pada kesehatan } \\
\text { mental dan jumlah } \\
\text { CD4 di antara pasien } \\
\text { HIV perempuan. }\end{array}$ & $\begin{array}{l}\text { Randomised Uji klinis ini dilakukan pada } 40 \text { responden wanita } \\
\text { Controlled usia 20-40 tahun yang positif HIV yang di rujuk ke } \\
\text { Trial (RCT) klinik VCT dan melakukan latihan aerobic dan } \\
\text { latihan kekuatan saat menerima layanan rutin VCT. } \\
\text { Intervensi dilakukan selama } 12 \text { minggu. Data } 30 \\
\text { peserta (kelompok eksperimen (14) dan kelompok } \\
\text { kontrol (16)) dianalisis (tingkat partisipasi } 75 \%) \text {. } \\
\text { Setelah program intervensi, perbedaan yang } \\
\text { signifikan dalam jumlah CD4 ditemukan antara } \\
\text { kedua kelompok (P } 1 / 40,01) \text {. }\end{array}$ \\
\hline $\begin{array}{c}\text { Naoroibam et } \\
a l, 2016\end{array}$ & India & $\begin{array}{l}\text { Untuk mempelajari } \\
\text { efek intervensi yoga } \\
\text { terpadu selama } 1 \\
\text { bulan terhadap } \\
\text { kecemasan, depresi, } \\
\text { dan jumlah CD4 } \\
\text { pada pasien } \\
\text { menderita infeksi } \\
\text { HIV-1 }\end{array}$ & $\begin{array}{l}\text { Randomized Pada } 44 \text { responden yang terinfeksi HIV-1 dari dua } \\
\text { Controlled pusat rehabilitasi HIV di Negara Bagian Manipur } \\
\text { Pilot (RCP) India secara acak menjadi dua kelompok: Yoga }(\mathrm{n}= \\
\text { 22; } 12 \text { laki-laki) dan kontrol }(\mathrm{n}=22 ; 14 \text { laki-laki). } \\
\text { Antar kelompok } \\
\text { perbandingan mengungkapkan penurunan skor } \\
\text { depresi yang signifikan }(\mathrm{F}[1,21]=5,64, \mathrm{p}<0,05) \\
\text { dan peningkatan CD4 yang signifikan jumlah }(\mathrm{F} \\
[1,21]=5,35, \mathrm{p}<0,05) \text { pada kelompok yoga } \\
\text { dibandingkan dengan kelompok kontrol. }\end{array}$ \\
\hline
\end{tabular}




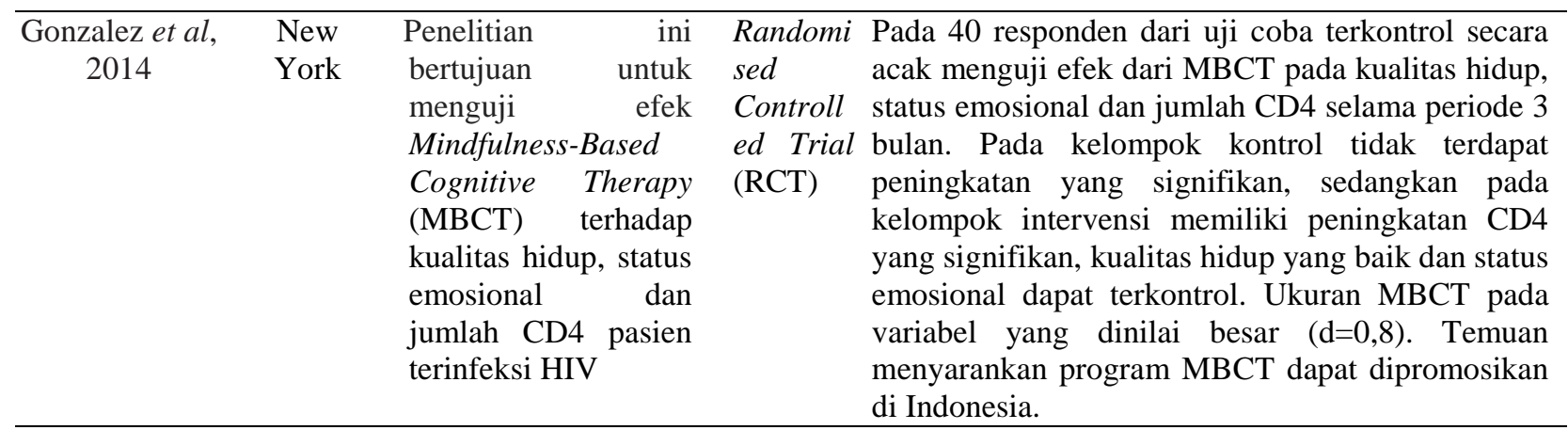

\begin{tabular}{|c|c|c|c|}
\hline $\begin{array}{c}\text { Nosrat et al, } \\
2017\end{array}$ & $\begin{array}{l}\text { New } \\
\text { York }\end{array}$ & $\begin{array}{l}\text { Penelitian ini } \\
\text { bertujuan untuk } \\
\text { menguji efek latihan } \\
\text { resistensi aktivasi } \\
\text { yang dirasakan } \\
\text { (yaitu, kelelahan } \\
\text { yang dirasakan) pada } \\
\text { pasien HIV dengan } \\
\text { gejala depresi }\end{array}$ & $\begin{array}{l}\text { Randomised } \text { Pada } 10 \text { responden usia } 33 \text { tahun keatas dengan } \\
\text { Controlled skor Centre for Epidemiologic Depression Scale } \\
\text { Trial (RCT) (CES-D) menyelesaikan } 20 \text { menit secara acak sesi } \\
\text { cross-over. Perubahan dianalisis menggunakan } \\
\text { tindakan berulang Analisis varians (ANOVA) } \\
\text { dengan tingkat signifikansi yang ditetapkan pada } \\
\mathrm{p}=0,05 \text {. Perbedaan yang signifikan dari waktu ke } \\
\text { waktu ditemukan di kedua mempengaruhi }(\mathrm{F} 1 / 4 \\
\\
2,63, \mathrm{p} 1 / 40,05) \text { dan dirasakan aktivasi }(\mathrm{F} 1 / 47,40, \mathrm{p} \\
<0,001)\end{array}$ \\
\hline
\end{tabular}

Nyamayaro et Afrika Tujuan dari penelitian Randomised Responden rata-rata berusia 18 tahun keatas yang al, $2018 \quad$ ini yaitu menyelidiki Controlled telah menggunakan ART selama minimal 4 bulan pengaruh Task- Trial (RCT)dan yang telah melakukan pemeriksaan jumlah Shifting Problem- CD4. Hasil studi ini mengatakan ada pengaruh Solving Therapy intervensi ntuk mengobati depresi dan mengatasi terhadap depresi hambatan kepatuhan ART di Afrika. Intervensi pada penderita HIV dilakukan menggunakan Task-Shifting Problemyang melakukan Solving Therapy untuk mengatasi depresi, terapi ARV kepatuhan ARV dapat diterima dan sudah terbukti dilakukan di Amerika Serikat.

\begin{tabular}{|c|c|c|}
\hline $\begin{array}{l}\text { McDermott et } \\
\text { al, } 2016\end{array}$ & Irlandia & 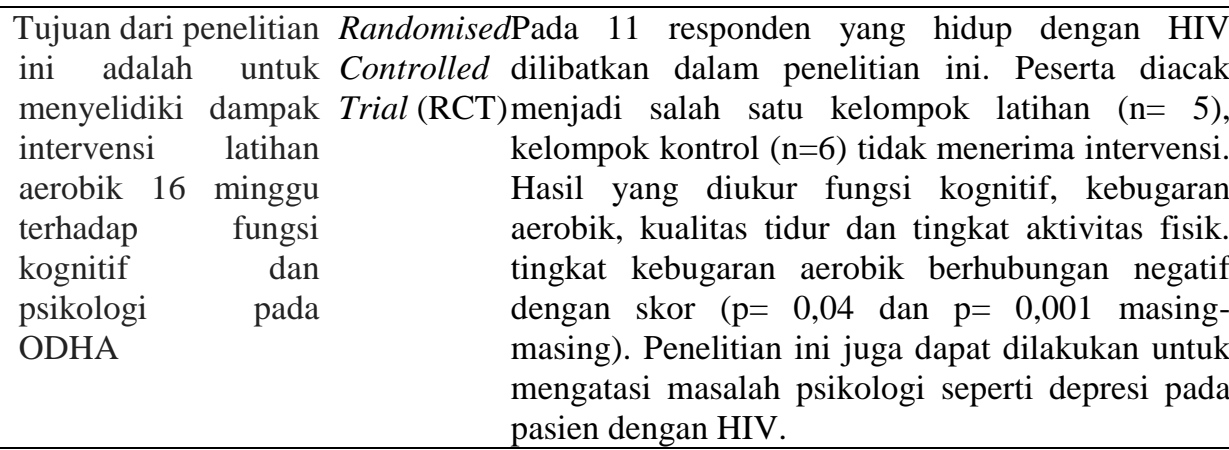 \\
\hline Fatma, 2019 & Indonesia & 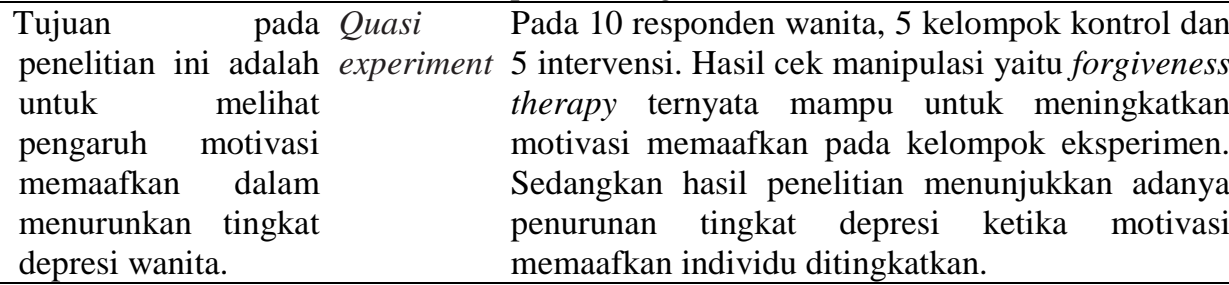 \\
\hline $\begin{array}{c}\text { Susanti et al, } \\
2018\end{array}$ & Indonesia & \begin{tabular}{lll}
\multicolumn{2}{l}{ Tujuan dari penelitian Quasi } & Pengambilan sampel dilakukan dengan teknik \\
ini adalah untuk experiment & simple random sampling berjumlah 45 subjek \\
menganalisis & & penelitian. Pengaruh locus of control, $\mathrm{p}=0,001$ \\
pengaruh locus of & $(29,8 \%)$. Pengaruh dukungan sebaya p= 0,001 \\
control & dan & $(52 \%)$. Pengaruh locus of control dan dukungan \\
dukungan & sebaya & sebaya $(\mathrm{p}=0,001, \mathrm{p}<0,05), 54 \%$ risiko depresi pada \\
terhadap & risiko & orang yang hidup dengan HIV dipengaruhi oleh \\
depresi & pada & faktor locus of control dan dukungan sebaya. \\
persahabatan & KDS &
\end{tabular} \\
\hline
\end{tabular}




\begin{tabular}{|c|c|c|c|c|}
\hline $\begin{array}{c}\text { Suyanti et al, } \\
2018\end{array}$ & Indonesia & $\begin{array}{l}\text { Penelitian } \\
\text { bertujuan } \\
\text { menentukan } \\
\text { pengaruh logoterapi, } \\
\text { terapi penerimaan } \\
\text { komitmen } \\
\text { pendidikan dan } \\
\text { keluarga pada stigma } \\
\text { diri dan depresi pada } \\
\text { ibu rumah tangga } \\
\text { yang hidup dengan } \\
\text { HIV/AIDS. }\end{array}$ & $\begin{array}{l}\text { Quasi } \\
\text { experiment }\end{array}$ & $\begin{array}{l}\text { Pada } 60 \text { responden ibu rumah tangga hidup dengan } \\
\text { HIV/AIDS usia 20-40 tahun yang tinggal bersama. } \\
\text { Pada pasien yang menerima logoterapi, terapi } \\
\text { penerimaan komitmen dan psikoedukasi keluarga } \\
\text { menunjukkan peningkatan signifikan pada self- } \\
\text { stigma dan depresi keseluruhan (p<0,05). } \\
\text { Kombinasi logoterapi, terapi penerimaan komitmen } \\
\text { dan psikoedukasi keluarga direkomendasikan } \\
\text { sebagai paket terapi untuk mengatasi stigma dan } \\
\text { depresi diri orang yang hidup dengan HIV / AIDS. }\end{array}$ \\
\hline $\begin{array}{l}\text { Lyon et al, } \\
\quad 2018\end{array}$ & $\begin{array}{l}\text { Wasington } \\
\text { DC }\end{array}$ & $\begin{array}{l}\text { Tujuan dari penelitian } \\
\text { ini adalah untuk } \\
\text { memeriksa } \\
\text { kemanjuran ACP } \\
\text { FAmily-CEntered } \\
\text { (FACE) dalam } \\
\text { meningkatkan } \\
\text { kemajuan } \\
\text { perencanaan } \\
\text { perawatan dan } \\
\text { memajukan } \\
\text { dokumentasi direktif } \\
\text { dalam catatan medis. }\end{array}$ & \multirow{2}{*}{\multicolumn{2}{|c|}{$\begin{array}{l}\text { RandomisedPasien sebanyak } 223 \text { usia rata-rata } 51 \text { tahun, } 56 \% \\
\text { Controlled pria, } 86 \% \text { Afrika-Amerika. } 199 \text { pasangan } \\
\text { Trial (RCT) berpartisipasi dalam intervensi. Pada awal, hanya } \\
13 \% \text { dari pasien arahan muka. Tiga bulan pasca } \\
\text { intervensi, meningkat menjadi } 59 \% \text { untuk FACE } \\
\text { ACP kelompok versus } 17 \% \text { pada kelompok kontrol } \\
\text { (p<0,0001). Antara Afrika-Amerika secara acak ke } \\
\text { FACE, 58\% telah menyelesaikan / } \\
\text { mendokumentasikan arahan muka versus } 20 \% \text { dari } \\
\text { kontrol (p<0,0001). } \\
\text { RandomisedPasien dewasa yang terinfeksi HIV diacak (n }=29) \\
\text { Controlled dalam kelompok terapi pijat } 1 \text { jam seminggu } \\
\text { Trial (RCT) selama } 4 \text { minggu dan kelompok kontrol. } \\
\text { Kecemasan dan depresi, hiperventilasi dan kualitas } \\
\text { hidup di evaluasi pada saat inklusi dan setelah } 4 \\
\text { minggu. Setelah terapi pijat } 4 \text { minggu, peningkatan } \\
\text { yang signifikan diamati hanya untuk Nijmegen, } \\
\text { kuesioner (p= 0,01) dan HADS-A (p= 0,04) } \\
\text { berlawanan dengan WHOQOL-HIV dan HADS-D. } \\
\text { Domain dari WHOQOL-HIV tidak membaik } \\
\text { setelah terapi pijat. Hasil setelah dilakukan terapi } \\
\text { pijat (p=0,04). }\end{array}$}} \\
\hline $\begin{array}{c}\text { Gregory et al, } \\
2017\end{array}$ & Belg & $\begin{array}{l}\text { Tujuan dari penelitian } \\
\text { ini adalah untuk } \\
\text { mengukur efek terapi } \\
\text { pijat pada } \\
\text { kecemasan, depresi, } \\
\text { hiperventilasi, dan } \\
\text { kualitas hidup pada } \\
\text { pasien } \\
\text { terinfeksi HIV. yang }\end{array}$ & & \\
\hline $\begin{array}{l}\text { Yang et al, } \\
2015\end{array}$ & China & $\begin{array}{l}\text { Tujuan dari penelitian } \\
\text { ini adalah untuk } \\
\text { menilai efek dari } \\
\text { terapi } \quad \text { berbasis } \\
\text { mindfulness (MBT) } \\
\text { pada hasil orang } \\
\text { yang hidup dengan } \\
\text { HIV. }\end{array}$ & $\begin{array}{l}\text { Randomised } \\
\text { Controlled } \\
\text { Trial (RCT) }\end{array}$ & $\begin{array}{l}d 7 \text { artikel menggambarkan hasil yang diperoleh } \\
\text { dengan total } 620 \text { orang yang terinfeksi HIV } \\
\text { terdaftar dalam } 6 \text { percobaan acak dan } 1 \text { percobaan } \\
\text { semu eksperimen dimasukkan dalam final meta- } \\
\text { analisis. Responden yang mendapatkan MBT } \\
\text { berpengalaman perasaan stres secara signifikan } \\
\text { menurun setelah } 8 \text { minggu }(\mathrm{p}=0,03) \mathrm{MBT} \text {, dan } \\
\text { perasaan menurun depresi setelah } 8 \text { minggu }(\mathrm{p}= \\
0,04) \text { dan } 6 \text { bulan }(\mathrm{p}=0,02) \text {. }\end{array}$ \\
\hline $\begin{array}{l}\text { Valeria et al, } \\
2015\end{array}$ & $\begin{array}{r}\text { Indon } \\
\mathrm{a}\end{array}$ & $\begin{array}{l}\text { Tujuan dari penelitian } \\
\text { ini adalah untuk } \\
\text { menentukan } \\
\text { karakteristik } \\
\text { dukungan keluarga, } \\
\text { harga diri dan } \\
\text { depresi pada wanita } \\
\text { dengan HIV/AIDS, } \\
\text { hubungan antara } \\
\text { dukungan keluarga, } \\
\text { harga diri dan } \\
\text { depresi. }\end{array}$ & $\begin{array}{l}\text { Cross- } \\
\text { sectional } \\
\text { study }\end{array}$ & $\begin{array}{l}\text { Pada } 99 \text { responden usia rata-rata } 36 \text { tahun, } \\
\text { diantaranya } 44,4 \% \text { adalah lulusan } \\
\text { menengah, 54,5\% menganggur dan } 91,9 \% \\
\text { memiliki HIV/AIDS selama lebih dari satu tahun. } \\
\text { Analisis regresi logistik biner menunjukkan tidak } \\
\text { hubungan yang signifikan antara dukungan } \\
\text { keluarga dan harga diri ( } \mathrm{p}=0,700) \text { dan depresi ( } \mathrm{p}= \\
\text { 0,396). Dukungan keluarga yang baik memiliki } \\
\text { efek perlindungan 1,3 kali (OR= 0,772; 95\% } \\
\text { CI:0,138-3,770) menuju peningkatan harga diri, } \\
\text { sedangkan dukungan keluarga miskin } \\
\text { meningkatkan risiko depresi } 1,5 \text { kali (OR = 1,477; } \\
\text { 95\% CI: 0,598-3,645) pada WLWHA yang } \\
\text { terinfeksi HIV / AIDS dari suami / pasangannya. }\end{array}$ \\
\hline
\end{tabular}




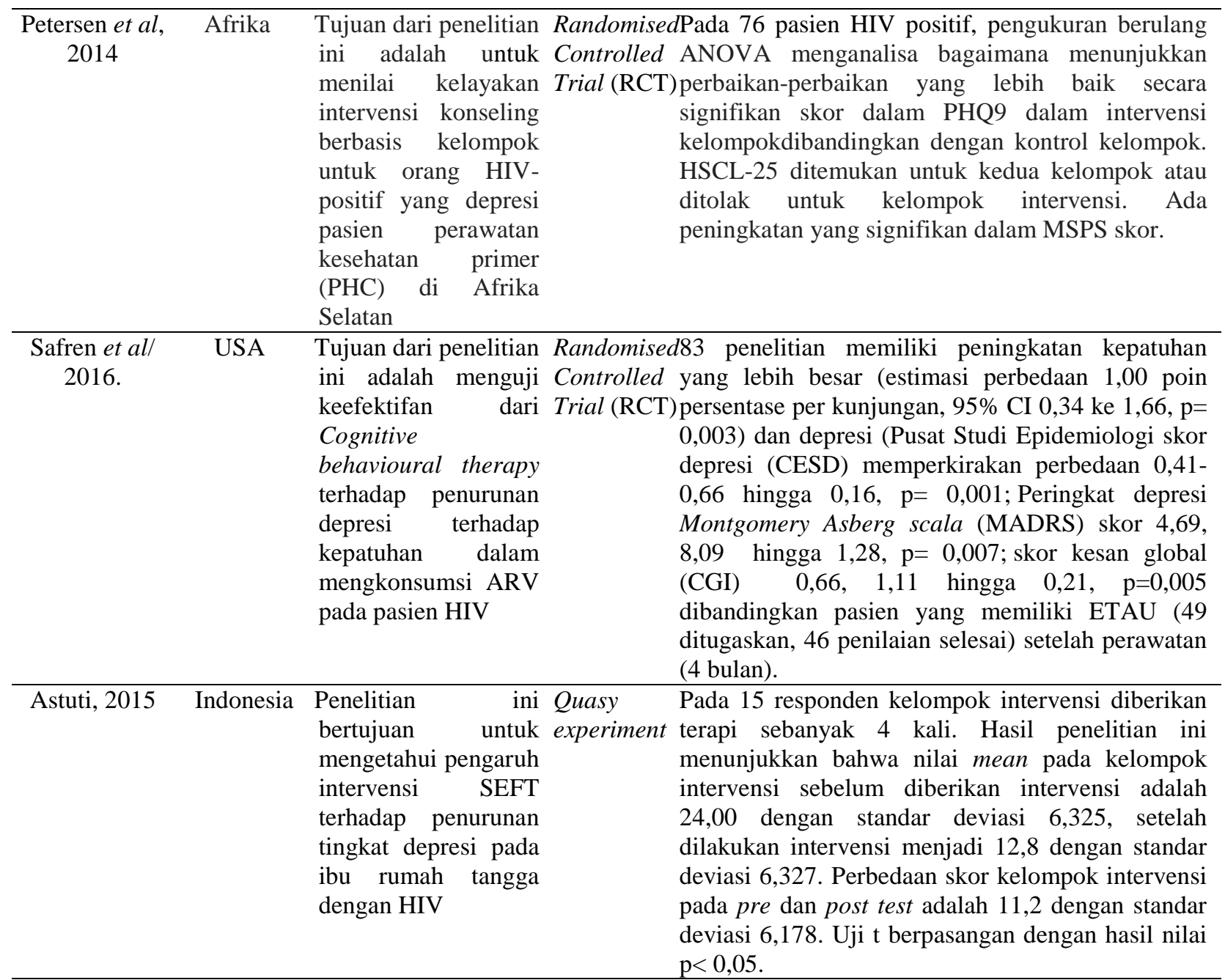

Setiyadi et al/ Indonesia Tujuan penelitian ini RandomizedPada 30 responden yang diberikan intervensi 2016 untuk menganalisis controlled hypnotherapy, tingkat depresi pada kelompok pengaruh hipnoterapi trial (RCT) hipnoterapi (rata-rata= 5,07; $\mathrm{SD}=5,45$ ) lebih terhadap perubahan depresi, kecemasan dan stres pada orang dengan HIV/AIDS (ODHA) di Kelompok Dukungan Sebaya rendah daripada pada kelompok kontrol (rata-rata= 17,73; $\mathrm{SD}=6,50)$ dan secara statistik signifikan $(\mathrm{p}<$ 0,001). Tingkat kecemasan pada kelompok hipnoterapi (rata-rata $=7,70 ; \mathrm{SD}=5,29)$ lebih rendah daripada pada kelompok kontrol (rata-rata= 20,77; $\mathrm{SD}=5,98)$ dan secara statistik signifikan $(\mathrm{p}<$ 0,001). Tingkat stres pada kelompok hipnoterapi (rata-rata $=7.77 ; \mathrm{SD}=6.37$ ) lebih rendah dari pada pada kelompok kontrol (rata-rata= 20.30; $\mathrm{SD}=$ 5.34) dan secara statistik signifikan ( $\mathrm{p}<0.001)$.

Tabel 1 menunjukan sintesa populasi penelitian berdasarkan artikel yang ditinjau. Artikel yang didapat berasal dari beberapa negara, dari 18 penelitian yang terpilih, penelitian dilakukan di Indonesia dan negara lain. Mayoritas studi dilakukan di negara Indonesia (Indonesia $=6$, Afrika $=2$, New York, USA $=3$, Jerman $=1$, Iran $=1$, India $=1$, Irlandia $=1$, Washington $\mathrm{DC}=$ 1, Belgium $=1$, China $=1$ ). Dari 18 studi penelitian, 12 merupakan Randomized Controlled Trial (RCT), 1 penelitian Randomized Controlled Pilot (RCP), 4 penelitian quasy experiment dan 1 penelitian cross sectional. Kriteria kelayakan yang dinyatakan untuk para responden dalam penelitian termasuk peserta yang jumlah CD4nya $200 \mathrm{sel} / \mathrm{ml}$, tidak ada masalah kesehatan mental. Ukuran sampel dalam penelitian bervariasi dari 10 respoden sampai 479 responden, rentang usia rata-rata peserta dalam penelitian ini berkisar $>18$ tahun keatas. Intervensi yang paling banyak dilakukan yaitu exercise (aerobic) terdapat 4 penelitian, sedangkan intervensi yang berikutnya yaitu mindfulness ada 2 penelitian, Integrated Yoga (IY), forgiveness therapy, Locus of Control and 
Peer Suppor, logo-therapy, acceptance, commitment therapy, family psychoeducation, FAmily CEntered (FACE) Advance Care, massage therapy, Cognitive behavioural therapy, Hypnotherapy, SEFT (Spiritual Emotional Freedom Technique) yang dapat menurunkan tingkat depresi dan jumlah CD4. Pengukuran tingkat depresi diukur dengan menggunakan kuisioner BDI (Beck Depression Inventory), Montgomery Asberg Scale (MADRS), Centre for Epidemiologic Depression Scale (CES-D), Hospital Anxiety and Depression Scale (HADS). Paling lama terapi dilakukan 2-3 kali perminggu selama kurang lebih 30-60 menit. Dari beberapa studi terdapat intervensi yang praktis dapat dilakukan dirumah. Lamanya intervensi berkisar 4 minggu sampai 24 minggu.

\section{PEMBAHASAN}

Tujuan dari sistematis ini adalah untuk memperoleh pemahaman yang lebih tentang intervensi terhadap depresi dan jumlah CD4 pasien HIV. Tinjauan ini menyarankan intervensi yang didapat sesuai penelitianpenelitian yang sudah ada dapat dilakukan pada pasien HIV untuk mengatasi depresi dan jumlah CD4. Baik intervensi standar ataupun non standar terutama gerakan tubuh, teknik pernapasan dan meditasi, komponen-komponen ini sudah masuk dalam terapi komplementer yang digunakan dalam memanajemen depresi. Hasil intervensi diatas terdapat pengaruh yang sigifikan terhadap kelompok yang mendapatkan intervensi. Intervensi diatas dapat mengurangi tingkat depresi, data 30 peserta (kelompok eksperimen $n=14$ dan kelompok kontrol $n=16$ ) dianalisis (tingkat partisipasi 75\%).

Setelah program intervensi exercise terdapat perbedaan yang signifikan dalam jumlah CD4 ditemukan antara kedua kelompok ( $\mathrm{P} 1 / 40,01)$, Sedangkan tingkat depresi diukur menggunakan BDI didapatkan hasil yang signifikan $(\mathrm{SMD}=0.90,96,95 \% \mathrm{CI}=-1,63$, $0,30, p=0,004$ ) (Dianatinasab et al., 2018; Heissel et al., 2019). Sedangkan pada Mindfulness-Based Cognitive Therapy (MBCT), variabel yang dinilai besar $(\mathrm{d}=0,8)$ memiliki pengaruh yang signifikan terhadap jumlah CD4 pasien HIV (Gonzalez-Garcia et al., 2014; Yang, Liu, Zhang, \& Liu, 2015). Literatur-literatur yang ada menyarankan bahwa peningkatan jumlah CD4 karena intervensi diatas bisa langsung melemahkan proses replikasi virus dan mengaktifkan respon sistem imun atau tidak langsung dengan metode penanganan stres yang lebih sehat dan kepatuhan terapi ARV. Temuan dari keseluruhan ulasan intervensi diatas mengidentifikasi bukti tambahan tentang pengaruhnya terhadap imunologis dan virus pada ODHA.

\section{SIMPULAN}

Tinjauan ini dapat menjawab dari tujuan penelitian yaitu menemukan beberapa literaatur-literatur yang dapat diberikan untuk mengurangi tingkat depresi dan jumlah CD4 pasien HIV danmenunjukan kompleksitas dari beberapa intervensi yang dapat dilakukan pada ODHA khususnya. Penelitian ini dapat membantu menginformasikan berbagai jenis intervensi yang dapat dilakukan ODHA dimasa mendatang. Secara keselurhan, intervensi yang dilakukan sangat sederhana dan hemat biaya, non-farmakologis untuk mengurangi tingkat depresi dan peningkatan jumlah CD4 pada pasien HIV/AIDS. Intervensi lainnya juga dapat meningkatkan kualitas hidup, menurunkan tingkat kecemasa, kelamahan dan meningkatkan efek pengobatan ART pasien ODHA.

\section{DAFTAR PUSTAKA}

Anderson, R., Freedland, K., RE, C., \& Lustman, P. J. (2001). The Prevalence of Comorbid Depression. Diabetes Care, 24(6), 1069-1078.

Aweto, H. A., Aiyegbusi, A. I., Ugonabo, A. J., \& Adeyemo, T. A. (2016). Effects of aerobic exercise on the pulmonary functions, respiratory symptoms and psychological status of people living with HIV. Journal of Research in Health Sciences, 16(1), 17-21.

Benton, T. D., Kee Ng, W. Y., Leung, D., Canetti, A., \& Karnik, N. (2019). Depression among Youth Living with HIV/AIDS. Child and Adolescent Psychiatric Clinics of North America, 28(3), 447-459. https://doi.org/10.1016/j.chc.2019.02.0 14

Dianatinasab, M., Fararouei, M., Padehban, V., Dianatinasab, A., Alimohamadi, Y., Beheshti, S., ... AminiLari, M. (2018). 
The effect of a 12-week combinational exercise program on CD4 count and mental health among HIV infected women: A randomized control trial. Journal of Exercise Science and Fitness, 16(1), 21-25. https://doi.org/10.1016/j.jesf.2018.02.0 01

Gonzalez-Garcia, M., Ferrer, M. J., Borras, X., Muñoz-Moreno, J. A., Miranda, C., Puig, J., ... Fumaz, C. R. (2014). Effectiveness of mindfulness-based cognitive therapy on the quality of life, emotional status, and CD4 cell count of patients aging with HIV infection. AIDS and Behavior, 18(4), 676-685. https://doi.org/10.1007/s10461-0130612-z

Grace, J. M., Semple, S. J., \& Combrink, S. (2015). Exercise therapy for human immunodeficiency virus/AIDS patients: Guidelines for clinical exercise therapists. Journal of Exercise Science and Fitness, 13(1), 49-56. https://doi.org/10.1016/j.jesf.2014.10.0 03

Gregory, R., Gilles, C., Aude, A., Laurie, L., Leïla, B., Jean-Cyr, Y., \& JeanChristophe, M. (2017). Effects of massage therapy on anxiety, depression, hyperventilation and quality of life in HIV infected patients: A randomized controlled trial. Complementary Therapies in Medicine, 32(December 2016), 109-114. https://doi.org/10.1016/j.ctim.2017.05.0 02

Haglund, M., Ang, A., Mooney, L., Gonzales, R., Chudzynski, J., Cooper, C. B., ... Rawson, R. A. (2015). Predictors of depression outcomes among abstinent methamphetamine-dependent individuals exposed to an exercise intervention. American Journal on Addictions, 24(3), 246-251. https://doi.org/10.1111/ajad.12175

Heissel, A., Zech, P., Rapp, M. A., Schuch, F. B., Lawrence, J. B., Kangas, M., \& Heinzel, S. (2019). Effects of exercise on depression and anxiety in persons living with HIV: A meta-analysis. Journal of Psychosomatic Research, 126(August), 109823. https://doi.org/10.1016/j.jpsychores.201 9.109823

Jaggers, J. R., Dudgeon, W., Blair, S. N., Sui, X., Burgess, S., Wilcox, S., \& Hand, G. A. (2013). A home-based exercise intervention to increase physical activity among people living with HIV: Study design of a randomized clinical trial. BMC Public Health, 13(1). https://doi.org/10.1186/1471-2458-13502

Jensen, W., Oechsle, K., Baumann, H. J., Mehnert, A., Klose, H., Bloch, W., ... Baumann, F. T. (2014). Effects of exercise training programs on physical performance and quality of life in patients with metastatic lung cancer undergoing palliative chemotherapy-A study protocol. Contemporary Clinical Trials, 37(1), 120-128. https://doi.org/10.1016/j.cct.2013.11.01 3

Kemenkes. (2017). Laporan Perkembangan HIV-AIDS. 1-565.

Kusuma, H. (2011). Hubungan Antara Depresi dan Dukungan Keluarga Dengan Kualitas Hidup Pasien HIV/AIDS yang Menjalani Perawatan di RSUP Cipto Mangunkusumo Jakarta. Universitas Indonesia, 20,21,7679,111-114,135-139. Retrieved from www.lib.ac.id

Lang, C. (1993). Using Relaxation and Exercise as Part of the Care of People Living with HIV/AIDS. Physiotherapy (United Kingdom), 79(6), 379-384. https://doi.org/10.1016/S00319406(10)60756-0

LaVoy, E. C., Bosch, J. A., Lowder, T. W., \& Simpson, R. J. (2013). Acute aerobic exercise in humans increases cytokine expression in CD27- but not CD27+ CD8+ T-cells. Brain, Behavior, and Immunity, 27(1), 54-62. https://doi.org/10.1016/j.bbi.2012.09.00 6 
Li, L., Lee, S. J., Thammawijaya, P., Jiraphongsa, C., \& Rotheram-Borus, M. J. (2009). Stigma, social support, and depression among people living with HIV in Thailand. AIDS Care Psychological and Socio-Medical Aspects of AIDS/HIV, 21(8), 10071013.

https://doi.org/10.1080/0954012080261 4358

Lox, C. L., McAuley, E., \& Tucker, R. S. (1996). Aerobic and resistance exercise training effects on body composition, muscular strength, and cardiovascular fitness in an HIV-1 population. International Journal of Behavioral Medicine, 3(1), 55-69. https://doi.org/10.1207/s15327558ijbm 0301_5

Lyon, M. E., Squires, L., D'Angelo, L. J., Benator, D., Scott, R. K., Greenberg, I. H., ... Wang, J. (2019). FAmilyCEntered (FACE) Advance Care Planning Among African-American and Non-African-American Adults Living With HIV in Washington, DC: A Randomized Controlled Trial to Increase Documentation and Health Equity. Journal of Pain and Symptom Management, 57(3), 607-616. https://doi.org/10.1016/j.jpainsymman. 2018.11.014

McDermott, A., Zaporojan, L., McNamara, P., Doherty, C. P., Redmond, J., Forde, C., ... Bergin, C. (2017). The effects of a 16-week aerobic exercise programme on cognitive function in people living with HIV. AIDS Care - Psychological and Socio-Medical Aspects of AIDS/HIV, 29(6), 667-674. https://doi.org/10.1080/09540121.2016. 1263723

Mkandla, K., Myezwa, H., \& Musenge, E. (2016). The effects of progressiveresisted exercises on muscle strength and health-related quality of life in persons with HIV-related polyneuropathy in Zimbabwe. AIDS Care Psychological and Socio-Medical Aspects of AIDS/HIV, 28(5), 639-643. https://doi.org/10.1080/09540121.2015.
1125418

Muñoz-Moreno, J. A. (2012). HIV \& Psychiatry.

Naoroibam, R., Metri, K., Bhargav, H., Nagaratna, R., \& Nagendra, H. (2016). Effect of Integrated Yoga (IY) on psychological states and CD4 counts of HIV-1 infected Patients: A Randomized controlled pilot study. International Journal of Yoga, 9(1), 57. https://doi.org/10.4103/09736131.171723

Nosrat, S., Whitworth, J. W., Dunsiger, S. I., SantaBarbara, N. J., \& Ciccolo, J. T. (2017). Acute effects of resistance exercise in a depressed HIV sample: The exercise for people who are immunocompromised (EPIC) study. Mental Health and Physical Activity, 12, 2-9. https://doi.org/10.1016/j.mhpa.2016.12. 002

Nwaka, I. I., Onwunzo, C. N., Ezeakunne, U., Ezeukwu, A. O., Ezugwu, U. A., Chigozie, U. I., \& Anieto, E. M. (2019). Effect of Aerobic Exercises and Resistance Exercises on Inflammatory Biomarkers and Fatigue in People Living with HIV Infection Undergoing Highly Active Antiretroviral Therapy; A Systematic Review. Indian Journal of Physiotherapy and Occupational Therapy - An International Journal, 13(4), 174. https://doi.org/10.5958/09735674.2019.00156.4

Nyamayaro, P., Bere, T., Magidson, J. F., Simms, V., O'Cleirigh, C., Chibanda, D., \& Abas, M. (2019). A Task-Shifting Problem-Solving Therapy Intervention for Depression and Barriers to Antiretroviral Therapy Adherence for People Living With HIV in Zimbabwe: Case Series. Cognitive and Behavioral Practice, \#pagerange\#. https://doi.org/10.1016/j.jad.2014.02.01 3

O’Brien, K. K., Tynan, A. M., Nixon, S. A., \& Glazier, R. H. (2016). Effectiveness 
of aerobic exercise for adults living with HIV: Systematic review and metaanalysis using the Cochrane Collaboration protocol. In $B M C$ Infectious Diseases (Vol. 16). https://doi.org/10.1186/s12879-016$1478-2$

Patil, R., Shimpi, A., Rairikar, S., Shyam, A., \& Sancheti, P. (2017). Effects of fitness training on physical fitness parameters and quality of life in human immunodeficiency virus-positive Indian females. Indian Journal of Sexually Transmitted Diseases, 38(1), 47-53. https://doi.org/10.4103/02537184.196886

Petersen, I., Hanass Hancock, J., Bhana, A., \& Govender, K. (2014). A group-based counselling intervention for depression comorbid with HIV/AIDS using a task shifting approach in South Africa: A randomized controlled pilot study. Journal of Affective Disorders, 158, 78-84.

https://doi.org/10.1016/j.jad.2014.02.01 3

Robinson, F. P., Mathews, H. L., \& WitekJanusek, L. (2003). Mindfulness-Based Stress Reduction in Individuals Infected with the Human Immunodeficiency Virus: The Journal of Alternative and Complementary Medicine, 9(5), 683694.

Ruiz S and Pedrol E, R. R. (2012). Physical Activity Associated with HIV. Journal of AIDS \& Clinical Research, 03(03), 1-4. https://doi.org/10.4172/21556113.s9-001

Safren, S. A., Bedoya, C. A., O’Cleirigh, C., Biello, K. B., Pinkston, M. M., Stein, M. D., .. Mayer, K. H. (2016). Cognitive behavioural therapy for adherence and depression in patients with HIV: a three-arm randomised controlled trial. The Lancet HIV, 3(11), e529-e538.

https://doi.org/10.1016/S2352-

3018(16)30053-4

Sri Suyanti, T., Anna Keliat, B., \& Catharina
Daulima, N. H. (2018). Effect of logotherapy, acceptance, commitment therapy, family psychoeducation on self-stigma, and depression on housewives living with HIV/AIDS. Enfermeria Clinica, 28, 98-101. https://doi.org/10.1016/S11308621(18)30046-9

Susanti, E., \& Beny, R. (2014). Effect of Locus of Control and Peer Support the Risk of Depression on People Living with HIV / AIDS in KDS Friendship Plus Kediri City. 2014(September), 228-235.

Unaids. (2019). 2018 Global HIV Statistics. 2(1), 1-6.

Valeria, J., Surilena, S., Budiman, Y., Djauzi, S., \& Indah, H. (2016). Family support is not a risk factor of negative selfesteem in HIV/AIDS women. Universa Medicina, $34(1), \quad 61$. https://doi.org/10.18051/univmed.2015. v34.61-67

Yang, Y., Liu, Y. H., Zhang, H. F., \& Liu, J. Y. (2015). Effectiveness of mindfulness-based stress reduction and mindfulness-based cognitive therapies on people living with HIV: A systematic review and meta-analysis. International Journal of Nursing Sciences, 2(3), 283-294. https://doi.org/10.1016/j.ijnss.2015.07.0 03

Zhao, L., Wu, H., Zhou, X., Wang, Q., Zhu, W., \& Chen, J. (2012). Effects of progressive muscular relaxation training on anxiety, depression and quality of life of endometriosis patients under gonadotrophin-releasing hormone agonist therapy. European Journal of Obstetrics and Gynecology and Reproductive Biology, 162(2), 211-215. https://doi.org/10.1016/j.ejogrb.2012.02 .029 